„Analecta Cracoviensia” 52 (2020), s. 29-53

DOI: https://doi.org/10.15633/acr.4044

Marta Ficoń

https://orcid.org/oooo-00o2-4952-9197

Uniwersytet Papieski Jana Pawła II w Krakowie

\title{
Antydemoniczny charakter sakramentu święceń
}

Idąc za wezwaniem Pisma Świętego przytoczonym przez papieża Franciszka w adhortacji apostolskiej Gaudete et exsultate, aby opierać się atakom diabła w nieustannej walce na drodze do świętości, kontynuujemy refleksję nad „potężną bronią, jaką daje nam Pan", a mianowicie nad sakramentami Kościoła. W poprzednim artykule pochyliliśmy się nad antydemonicznym wymiarem sakramentu namaszczenia chorych ${ }^{2}$, a obecnie skupimy się na tym aspekcie w przypadku jednego z sakramentów ustanowionych przez Chrystusa w służbie komunii, czyli sakramentu święceń.

Mówiąc o sakramentach w bulli Exsultate Deo z 1439 roku, Sobór Florencki stwierdził, że „spośród nich pięć pierwszych służy osobistemu udoskonaleniu duchowemu każdego człowieka, dwa ostatnie - rządzeniu całym Kościołem i (jego) wzrostowi (...); przez święcenia (...) Kościół jest rządzony, przez małżeństwo fizycznie się pomnaża”3. Z kolei współczesny Katechizm Kościoła Katolickiego głosi, że te dwa sakramenty są nastawione na zbawienie innych ludzi, a przez tę służbę bliźnim przyczyniają się również do zbawienia osobistego; udzielają także „szczególnego posłania w Kościele i służą budowaniu

\footnotetext{
1 Franciszek, Adhortacja apostolska Gaudete et exsultate [dalej: GE], nr 162, http://www. vatican.va/content/francesco/pl/apost_exhortations/documents/papa-francesco_esortazioneap_20180319_gaudete-et-exsultate.html (30.12.2019).

2 Zob. M. Ficoń, Antydemoniczny charakter sakramentu namaszczenia chorych, „Analecta Cracoviensia" 51 (2019), s. 35-64.

3 Breviarium fidei. Wybór doktrynalnych wypowiedzi Kościoła [dalej: BF], red. I. Bokwa, Poznań 2007 , nr 276.
} 
Ludu Bożego" ${ }^{4}$. Nauczanie Magisterium zwraca zatem uwagę na inną specyfikę tych dwóch świętych znaków w stosunku do pozostałych pięciu. Wszystkie sakramenty są relacją interpersonalną człowieka z Chrystusem, a dzięki niej także $\mathrm{z}$ innymi ludźmi. Ich skutki dotykają bezpośrednio przyjmujących je, a pośrednio mają wpływ na otoczenie. W przypadku tych dwóch sakramentów perspektywa jest niejako odwrócona - akcent kładzie się raczej na innych na skutkach sakramentu święceń dla wiernych oraz na konsekwencjach sakramentu małżeństwa dla współmałżonka i całego Kościoła. Celowość celebracji tych dwóch sakramentów polega nie tyle na uświęceniu samego przyjmującego, ile na uświęceniu i służbie drugiemu człowiekowi ${ }^{5}$. Dlatego katechizm nazywa je „sakramentami w służbie komunii”. Ową komunię można rozumieć trojako: jako wspólnotę ludzi z Bogiem, jako wspólnotę ludzi między sobą oraz jako wspólnotę Osób Boskich w Trójcy Świętej. W tym ostatnim ujęciu byłaby to służba Ojcu, Synowi i Duchowi Świętemu, czyli Bogu Trójjedynemu. Jego istotę można by oddać jako proegzystencję - czyli „bycie dla” - na tym opiera się wszelka inna komunia międzyludzka i eklezjalna. Służyć „byciu dla” jest całkowitym przeciwieństwem „bycia przeciwko”, czyli istoty i sztandarowego hasła Szatana, do którego można zastosować słowa Jezusa: „kto nie jest ze Mną, jest przeciwko Mnie; a kto nie zbiera ze Mną, ten rozprasza” (Łk 11, 23), a rozproszenie, zniszczenie wspólnoty i podział jest istotą słowa „diabel”. ${ }^{\mathrm{Na}}$ tym przede wszystkim polega podstawowy, ale nie jedyny objaw antydemoniczności tych dwóch świętych znaków.

\section{Sakrament święceń w aspekcie antydemonicznym ${ }^{7}$}

Jak naucza Magisterium, poprzez nałożenie rąk i modlitwę święceń przyjmującemu ten sakrament zostaje udzielony Duch Święty, który posyła go, uświęca swą łaską i daje władzę sprawowania posługi w imię Chrystusa oraz nadaje jego działaniom duchową skuteczność. Łaska Ducha właściwa dla

4 Katechizm Kościoła Katolickiego [dalej: KKK], Poznań 1994, nr 1534.

5 Gerhard Ludwig Müller pisze o święceniach: „Udzielona przez nie łaska nie służy przede wszystkim osobistemu uświęceniu, ale właśnie budowaniu Kościoła przez posługiwanie słowu i sakramentom, czyli uświęcaniu ludzi” (G. L. Müller, Dogmatyka katolicka, przeł. W. Szymona, Kraków 2015, s. 766).

6 Por. Jan Paweł II, Wierzę w Boga Ojca Stworzyciela, Città del Vaticano 1987, s. 361.

7 Pomimo niewątpliwych zasług diakonów w służbie Chrystusowi, Kościołowi i jego jedności, ze względu na obszerność tematu bardziej szczegółowo zajmiemy się tylko antydemonicznymi aspektami kapłaństwa urzędowego, które reprezentują biskupi i prezbiterzy. 
sakramentu święceń upodabnia wyświęconego do Chrystusa Kapłana, Nauczyciela i Pasterza oraz wyciska nieusuwalne znamię sługi Jezusa i Kościoła, czyli zmienia go na płaszczyźnie ontologicznej. Odtąd jest on nieodwracalnie i trwale włączony w określony stan życia oraz posłany do wykonywania posługi pasterskiej zakorzenionej w jego istocie i ogarniającej całą jego egzystencję. W sakramencie święceń osoba wyświęcona otrzymuje łaskę, która pozwala jej brać udział nie tylko w zbawczej posłudze i mocy Jezusa, lecz także w Jego pasterskiej miłości oraz znajduje gwarancję otrzymania wszelkich łask Bożych koniecznych do właściwego sprawowania powierzonej jej posługi ${ }^{8}$.

Tomasz z Akwinu podkreślił, że wyświęceni szafarze są „tylko posługaczami i jakby narzędziami życia, które spływa od głowy na członki"', mając na uwadze to, iż są sługami Chrystusa, którzy przedłużają i pełnią Jego dzieło na ziemi. W nich Chrystus nadal naucza, uświęca i służy ludowi Bożemu, dając im udział w swoim jedynym kapłaństwie i swej świętej władzy. W kapłańskiej służbie Kościołowi Chrystus jest obecny jako „Głowa swego ciała”, „Nauczyciel Prawdy”, „Pasterz swej trzody”, „Arcykapłan odkupieńczej ofiary”, dlatego Kościół naucza o tym, że prezbiter na mocy sakramentu święceń działa in persona Christi Capitis, czyli „w osobie Chrystusa - Głowy”. Jak wiadomo, dzieło całego życia Chrystusa stanowi tajemnicę odkupienia, począwszy od wcielenia, poprzez wydarzenie krzyża, aż po zmartwychwstanie, nie pomijając Jego nauczania, uzdrowień i egzorcyzmów. Obecność królestwa Bożego, które przyszło w Jego osobie, jest porażką królestwa Szatana: „jeśli Ja mocą Ducha Bożego wyrzucam złe duchy, to istotnie przyszło do was królestwo Boże" (Mt 12, 28). Natomiast Jego działalność egzorcystyczna wyzwala ludzi spod władzy złych duchów i uprzedza zwycięstwo Jezusa nad „władcą tego świata” $(\mathrm{J} 12,31)$, którego dokona na krzyżu ${ }^{11} \mathrm{i}$ wtedy „przyciągnie wszystkich do siebie” $(\mathrm{J} 12,32)$. W celu kontynuacji zbawczej misji Chrystus mocą swego autorytetu powołuje i ustanawia Dwunastu, ,aby Mu towarzyszyli, by mógł wysyłać ich na głoszenie nauki, i by mieli władzę wypędzać złe duchy” (Mk 3, 14-15).

8 Por. Jan Paweł II, Adhortacja posynodalna Pastores dabo vobis [dalej: PDV], nr 7o, http:// w2.vatican.va/content/john-paul-ii/pl/apost_exhortations/documents/hf_jp-ii_exh_25031992_pastoresdabo-vobis.html (30.12.2019); KKK 1585; G. L. Müller, Dogmatyka katolicka, dz. cyt., s. 752-753.

9 Tomasz z Akwinu, Suma teologiczna, t. 31: Sakrament chorych (Supl. 29-33); Kapłaństwo (Supl. 34-40), przełożył i w objaśnienia zaopatrzył R. Kostecki, London 1985, zag. 36, art. 3, ad. 1.

${ }_{10}$ KKK 1548, zob. KKK 1581; BF 978; Sobór Watykański II, Dekret o posłudze i życiu prezbiterów Presbyterorum ordinis [dalej: DP], nr 2, w: Sobór Watykański II, Konstytucje, dekrety, deklaracje, red. M. Przybył, Poznań 2002.

${ }^{11}$ Zob. KKK 517, 550. 
Nadaje im szczególną władzę wobec przyszłej wspólnoty, jak i w perspektywie uniwersalnej ewangelizacji. W dniu Pięćdziesiątnicy wylewa na nich pełnię Ducha Świętego i pełnię władzy działania w Jego imieniu ku zbawieniu Kościoła i świata, aby przyprowadzili do Niego wszystkich ludzi. To ta sama mesjańska władza pochodząca od Ojca, której pełnię otrzymał Jezus i która w pełni objawiła się w zmartwychwstaniu (zob. Mt 28, 18-20). Apostołowie wypełniają zatem nie swoją misję, lecz misję Jezusa, a pomiędzy powierzonym im urzędem i tym posłaniem istnieje ścisła więź (zob. Mt 10, 40; Łk 10, 16). Ich następcy - biskupi oraz ich współpracownicy, czyli prezbiterzy - mogą to czynić dzięki darmowemu uczestnictwu w łasce Chrystusa i Jego Ducha poprzez sakrament święceń i tym samym kontynuować Boże dzieło zbawienia dla dobra ludzi. W dziele tym zawiera się również walka z mocami ciemności ${ }^{12}$. Papież Pius XI zwrócił uwagę na ten aspekt w jednej z encyklik: „biskupi i kapłani, tworząc zwarty i wybrany hufiec, tak ochoczo wezwanie Najwyższego Sternika Kościoła przyjęli, że coraz żywszym pochodem po same krańce ziemi sięgają w tej myśli, żeby wszędzie staczać pokojowe, lecz uporczywe boje prawdy przeciw błędom, światła przeciw ciemnościom i Królestwa Bożego przeciw panowaniu szatana"13. Osoby wyświęcone mają zatem za zadanie pomagać ludowi Bożemu, prowadzić go do doskonałości, służyć mu i budować go między innymi poprzez głoszenie słowa Bożego i nauczanie, celebrację liturgii, dzieła miłości na wzór Jezusa wobec powierzonych im wiernych, w celu kontynuacji odkupieńczego dzieła Jezusa, który przeszedł, „dobrze czyniąc i uzdrawiając wszystkich, którzy byli pod władzą diabła” (Dz 10, 38).

Uzdolnienie biskupów, prezbiterów i diakonów do realizacji tego zadania poprzez sakrament święceń nie zamyka się tylko w obrębie pomocy i służby innym, ale ma duży wpływ także na samego wyświęconego. Będąc bowiem sługą na wzór Chrystusa Kapłana, Pasterza i Proroka oraz wypełniając chętnie, z pokorą i męstwem swoje apostolskie zadania, sam doznaje uświęcenia i wstępuje na wyższy poziom doskonałości: „jest przebóstwiany i przebóstwia”"14. Szczególna łaska tego sakramentu umożliwia pełniącemu posługę kapłańską otrzymanie stałego namaszczenia Duchem, czyli uświęcenia, aby przez niego Chrystus pozostawał stale obecny. Poświęcenie się Chrystusowi i namaszczenie

${ }^{12}$ Zob. PDV 14.

${ }_{13}$ Pius XI, Encyklika Ad catholici sacerdotii, https://opoka.org.pl/biblioteka/W/WP/pius_xi/ encykliki/ad_catholici_sacerdotii_20121935.html (30.12.2019).

${ }^{14}$ KKK 1589; zob. Sobór Watykański II, Konstytucja Lumen gentium [dalej: LG], nr 41, w: Sobór Watykański II, Konstytucje, dekrety, deklaracje, dz. cyt. 
Duchem idą w parze, więc Kościół domaga się od powołanych osobistej konsekracji, by służba kapłańska nie była wykonywana w sposób zewnętrzny, lecz była ofiarą z samego siebie dla dobra Kościoła i wszystkich ludzi. Dzięki temu, że osobiste uświęcenie i posługa są nierozłączne, wyświęcony szafarz ewangelizuje siebie w ewangelizacji, postępuje w świętości, pełniąc posługę uświęcenia, konsekruje siebie Bogu, powierzając $\mathrm{Mu}$ innych jako miłą $\mathrm{Mu}$ ofiarę ${ }^{15}$.

Chociaż niegodność i grzeszność szafarzy nie stanowi przeszkody dla owoców łaski, i jak pisał Augustyn z Hippony, sługa pyszny „należy do diabła, jednak daru Chrystusa nie plami" ${ }^{\prime 16}$, to jednak wewnętrzna logika daru otrzymanego w sakramencie święceń domaga się, by życie duchowe wyświęconego współgrało z powierzoną mu misją oraz żeby apostolska działalność Kościoła pozostawała niezagrożona i skuteczna, zaś władza Szatana nad tym światem nie triumfowała. Dlatego wyświęceni zachęcani są do opierania się na mocy Bożej, do wiary i poświęcenia się z ufnością posłudze oraz do uświadomienia sobie, że nie są sami i że Bóg może pogłębić w nich miłośćc ${ }^{17}$. Jest to szczególnie ważne wtedy, gdy osoby wyświęcone nieustannie doznają ataków ze strony Złego jako osoby pełniące szczególną posługę w Kościele i w świecie, władne głosić Ewangelię, uzdrawiać i wyrzucać złe duchy (por. Mk 6, 12-13). Ta ostatnia aktywność stanowi przedmiot naszej szczególnej uwagi ze względu na wspomniane na początku wezwanie do walki duchowej. Przede wszystkim ważne jest jednak ukazanie prawdy, że owo „wyrzucanie złych duchów” nie dotyczy

15 Por. K. Guzowski, Duch dialogujący, Lublin 2016, s. 251, 253; zob. DP 12.

16 KKK 1584; por. także KKK 1550; BF 436, 979.

${ }_{17}$ Zob. DP 22. Grzegorz z Nazjanzu pisał: „Trzeba zacząć od oczyszczenia siebie, zanim będzie się oczyszczało innych; trzeba posiąść naukę, by móc uczyć; trzeba stać się światłem, by oświecać, samemu zbliżyć się do Boga, by innych do Niego przybliżać, być uświęconym, by uświęcać, prowadzić za rękę i radzić rozumnie. Wiem, czyimi jesteśmy sługami, w jakim stanie się znajdujemy i kim jest Ten, do kogo zmierzamy. Znam wielkość Boga i słabość człowieka, ale także jego moc. [Kim więc jest kapłan? Jest] obrońcą prawdy, wznosi się z aniołami, wielbi z archaniołami, składa na ołtarzu dary ofiarne, uczestniczy w kapłaństwie Chrystusa, odnawia stworzenie, przywraca w nim obraz Boży, przysposabia je do świata wyższego i, co najważniejsze: jest przebóstwiany i przebóstwia” (cyt. za KKK 1589). Z kolei Tomasz z Akwinu podkreślił, że „świętość życia jest więc do święceń absolutnie wymagana i jest nakazana. Ważność jednak sakramentu nie zależy od niej” (Suma teologiczna, t. 31, dz. cyt., zag. 36, art. 1, odpowiedź); a także uważał, że do sprawowania należycie urzędu kapłańskiego trzeba posiadać cnotę i świętość w stopniu wysokim „dlatego wymaga się u święconych posiadania łaski uświęcającej, dzięki której mogą być policzeni w poczet wiernych Chrystusowych. Lecz przez otrzymanie sakramentu kapłaństwa otrzymują oni dar łaski obfitszej, która czyni ich zdolnymi do podejmowania wielkich dzieł" (Suma teologiczna, t. 31, dz. cyt., zag. 35, art. 1, ad. 3). 
jedynie posługi egzorcystów w Kościele, lecz obejmuje wszystkie aspekty posługi każdego wyświęconego szafarza.

\section{Funkcja prorocka - głoszenie „nauki z mocą” (Mk 1, 27)}

Przede wszystkim, wskutek wylania Ducha podczas święceń, biskupi, prezbiterzy i diakoni zostają zobowiązani i uzdolnieni przez Chrystusa do głoszenia słowa Bożego oraz ewangelizacji wszystkich narodów jako Jego świadkowie i słudzy (por. Mt 28, 18-20; Dz 1, 8). Ogłaszają zatem i nauczają o Chrystusie, który jako wcielony Syn Boży ,jest jedynym, doskonałym i ostatecznym Słowem Ojca. W Nim powiedział On wszystko i nie będzie już innego słowa oprócz Niego" ${ }^{\prime 18}$. Wyjaśniają Pismo Święte i prawdy wiary, by wzbudzić i podtrzymywać wiarę wśród powierzonych sobie ludzi, doprowadzić ich do praktykowania jej w życiu i oddalić od nich błędy, ponieważ Bóg „pragnie, by wszyscy ludzie zostali zbawieni i doszli do poznania prawdy" ( $1 \mathrm{Tm} 2,4)$. Jest to misja fundamentalna, ponieważ Ewangelia stanowi dla Kościoła źródło całego jego życia, zaś dla niewierzących jest przyczynkiem i źródłem wiary, która „rodzi się z tego, co się słyszy, tym zaś, co się słyszy, jest słowo Chrystusa" (Rz 10, 17). W ten sposób tworzą i gromadzą wspólnotę wierzących, których kapłańska posługa ewangelizacji powinna doprowadzić do świadomego i dobrowolnego przyjęcia dzieła Bożego na poziomie nie tyle teoretycznym, ile egzystencjalnym, do nawrócenia i świętości, do oddania chwały Bogu oraz do odrzucenia zła i jego prowokatora ${ }^{19}$. Dlatego diabeł stara się wszelkimi sposobami powstrzymać dzieło ewangelizacji ludzi, „zabrać słowo z ich serca, żeby nie uwierzyli i nie byli zbawieni" (Łk 8, 12).

W tej misji ważne jest, by wyświęceni, głosząc wszystkim ludziom Ewangelię, wierzyli w to, co przeczytali i rozważyli, nauczali tego, w co uwierzyli, oraz naśladowali to, czego nauczają ${ }^{20}$. Dlatego od formacji przyszłych wyświęconych szafarzy oraz od troski o osobiste uświęcenie w posłudze i o ciągłą odnowę duszpasterskiego zaangażowania zależy przyszłość ewangelizacji ludzkości. Ta formacyjna aktywność Kościoła stanowi kontynuację dzieła Chrystusa, które opisuje ewangelista Marek: „[Jezus] przywołał do siebie tych, których sam chciał, a oni przyszli do Niego. I ustanowił Dwunastu, aby Mu towarzyszyli,

\footnotetext{
18 KKK 65.

19 Zob. LG 20, 25; DP 2, 4.

20 Zob. LG 28.
} 
by mógł wysyłać ich na głoszenie nauki i by mieli władzę wypędzać złe duchy" $\left(\mathrm{Mk}_{3}, 13-15\right)^{21}$.

Walka z mocami ciemności wpisana jest w dzieło głoszenia Dobrej Nowiny i stanowi jej integralną część. Chrystus „posłał Apostołów, których napełnił Duchem Świętym (...), aby głosząc Ewangelię wszystkiemu stworzeniu, zwiastowali, że Syn Boży swoją śmiercią i zmartwychwstaniem wyrwał nas z mocy szatana $(\mathrm{Dz} 26,18)$ i uwolnił od śmierci oraz przeniósł do królestwa Ojca" ${ }^{32}$, ale nie chodzi tylko o to, by głosić Go jako Sprawcę zbawienia i Zwycięzcę diabła, ale także o to, by uobecniać Go jako takiego w Jego słowie, sakramentach i dziełach miłości oraz by położyć akcent na tym, że Jego słowo i On jako Słowo ma moc odstraszającą demony. O mocy słowa Bożego wielokrotnie przypomina Biblia i Magisterium Ecclesiae. Autorzy nowotestamentowi piszą, że Ewangelia jest „mocą Bożą ku zbawieniu dla każdego wierzącego” (Rz $1,16)$, a jej głoszenie „ukazywaniem ducha i mocy, aby wiara wasza opierała się nie na mądrości ludzkiej, lecz na mocy Bożej" (1 Kor 2, 4-5). Słowo Boże jest ,żywe”, , ,skuteczne i ostrzejsze niż wszelki miecz obosieczny, przenikające aż do rozdzielenia duszy i ducha, stawów i szpiku, zdolne osądzić pragnienia i myśli serca” (Hbr 4, 12), a wszystkim, którzy Je z wiarą przyjęli, „dało moc, aby się stali dziećmi Bożymi” (J 1, 12). Dlatego ojcowie Soboru Watykańskiego II nauczają, że „tak wielka tkwi w słowie Bożym moc i potęga, że jest ono dla Kościoła podporą i siłą żywotną, a dla synów Kościoła utwierdzeniem wiary, pokarmem duszy oraz źródłem czystym i stałym życia duchowego" ${ }^{23}$. Papież Franciszek napisał natomiast, iż słowo Boże zachęca do walki z diabłem i do oparcia się jego atakom (por. Ef 6, 11. 16), jego głoszenie „przezwycięża opór Złego” i jest źródłem radości Jezusa, zaś jego rozważanie stanowi „potężną bron" w duchowych zmaganiach $\mathrm{z}$,księciem zła”"

$\mathrm{Na}$ to, że moc słowa Bożego nie tylko podtrzymuje i warunkuje życie w Chrystusie (co samo w sobie jest antydemoniczne), lecz także jest ono władne wyrzucać złe duchy i odpierać szatańskie pokusy, wskazują chociażby opisy egzorcyzmów Jezusa i scena kuszenia na pustyni. Warto zauważyć, że pierwszym cudownym wydarzeniem opisanym na kartach Ewangelii

${ }^{21}$ Zob. PDV 2.

${ }^{22}$ Sobór Watykański II, Konstytucja o liturgii świętej Sacrosanctum Concilium [dalej: SC], nr 6, w: Sobór Watykański II, Konstytucje, dekrety, deklaracje, dz. cyt..

${ }^{23}$ Sobór Watykański II, Konstytucja dogmatyczna o Objawieniu Bożym Dei verbum, nr 21, w: Sobór Watykański II, Konstytucje, dekrety, deklaracje, dz. cyt.

${ }^{24}$ GE 159, 162. 
Markowej jest uwolnienie opętanego w synagodze w Kafarnaum. Najpierw jednak Jezus nauczał, wywołując wśród słuchaczy zdumienie, ponieważ uczył ich ,jak ten, który ma władzę, a nie jak uczeni w Piśmie” (Mk 1, 22). Następnie spotkał człowieka udręczonego przez złego ducha, który natychmiast wyjawił cel przyjścia na świat Syna Bożego: „Czego chcesz od nas, Jezusie Nazarejczyku? Przyszedłeś nas zgubić” (Mk 1, 23). Jezus pokazał jednak, że nie należy $\mathrm{z}$ demonami wchodzić $\mathrm{w}$ dyskusję i surowo przykazał mu: „Milcz i wyjdź z niego!” (Mk 1, 25). Po uwolnieniu opętanego obserwatorzy zauważyli, że jest to „nowa jakaś nauka z mocą. Nawet duchom nieczystym rozkazuje i są Mu posłuszne” (Mk 1, 27). Ewangelista Łukasz dodaje, że „słowo Jego było pełne mocy” (Łk 4, 31), zaś obecni przy tym świadkowie dziwili się: "Cóż to za słowo, że z władzą i mocą rozkazuje nawet duchom nieczystym, i wychodzą" (Łk 4, 36). Egzorcystyczną moc słowa Bożego podkreśla również scena kuszenia Jezusa na pustyni, kiedy odrzuca On każdą pokusę ze strony diabła cytatem z Pisma Świętego i mocą swego słowa (zob. Mt 4, 4. 7. 10; $Ł k$ 4, 4. 8. 12). Tą zasadą kierują się również egzorcyści, proklamując Ewangelię podczas rytuału egzorcyzmu - to znak obecności Chrystusa, który własnym słowem głoszonym w Kościele skutecznie działa, uzdrawia ludzkie choroby i dolegliwości tu i teraz. W nowym rytuale ukazano „egzorcyzmującą moc słowa Bożego, które jest dla udręczonego zbawieniem i ochroną" ${ }^{25}$. Wykonując zatem swą misję głoszenia Dobrej Nowiny wszystkim ludziom, wyświęceni ukazują moc i potęgę słowa Bożego, przez które Chrystus nadal naucza swój lud i wyzwala go spod panowania ciemności.

\section{Funkcja uświęcająca - „Sprawujemy} kult w Duchu Bożym" (Flp 3, 3)

Kolejnym zadaniem, które Jezus powierzył apostołom, a potem ich następcom biskupom i ich współpracownikom, jest kult Boga i celebracja świętych tajemnic dla uświęcenia wiernych, zwłaszcza sprawowanie Eucharystii (zob. Łk 22, 19), z której ich posługa czerpie moc, rozwiązywanie więzów grzechu (zob. Mt 16, 18-19; 18, 18; J 20, 22-23) i udzielanie chrztu w imię Trójcy Świętej (zob. Mt 28, 19). Pod kierownictwem i nadzorem biskupa - „szafarza łaski najwyższego kapłaństwa”26 dokonuje się zatem należyte sprawowanie sakramentów i oddawanie czci Bogu w liturgii, która jest wykonywaniem

${ }_{25}$ P. Towarek, Egzorcyzm. Historia, liturgia, teologia, Olsztyn 2013, s. 160-161.

${ }^{26}$ LG 26. 
kapłańskiego urzędu Jezusa Chrystusa. Dzięki niemu Chrystus zawsze jest obecny w swym Kościele nie tylko, jak już wspomniano, w swym słowie, lecz także w czynnościach liturgicznych, szczególnie w Ofierze mszy świętej, czy to w osobie odprawiającego, kiedy ofiaruje się przez posługę prezbiterów, tak jak kiedyś ofiarował się na krzyżu, czy to pod postaciami eucharystycznymi, oraz $\mathrm{w}$ innych sakramentach i w modlitwie Kościoła, prowadząc nadal w swych sługach dzieło uświęcenia swego ludu i oddawania chwały Bogu Ojcu w Duchu Świętym ${ }^{27}$. Ustanawiając urząd kapłański Nowego Przymierza i dając mu świętą władzę, Chrystus zadbał o rozwój kapłaństwa powszechnego wiernych. Jako pomocnicy Boga w dziele uświęcenia kapłani nie tylko udzielają sakramentów, ale też uczą, jak owocnie zjednoczyć się w nich z Chrystusem, zwłaszcza w Eucharystii (w której ofiarują swe życie Bogu), jak pokutować, jak się modlić, praktykować rady ewangeliczne, wychwalać Pana i dziękować $\mathrm{Mu}^{28}$. Dbając w ten sposób o owocność liturgii, wyświęceni szafarze przyczyniają się do wzrostu duchowego i udoskonalenia wiernych w świętości, nie dając tym samym miejsca dla działania złych duchów (zob. Łk 11, 24-26).

Samo sprawowanie przez nich sakramentów i rozdzielanie przyjmującym je zawartej w nich łaski Chrystusa $z$ natury ma znaczenie antydemoniczne, przede wszystkim z tego powodu, że są owocem i czerpią moc z Misterium Paschalnego Chrystusa, który przyszedł, by „zniszczyć dzieła diabła” (1 J 3, 8). Każdy z sakramentów na swój sposób wyłącza przyjmującego go z wiarą człowieka spod panowania grzechu i Szatana, dlatego można powiedzieć, że wyświęceni jako szafarze prawie wszystkich sakramentów, działając in persona Christi, przyczyniają się do „wyrzucania palcem Bożym złych duchów” (Łk 11, 20) i w konsekwencji do szerzenia królestwa Bożego.

Towarzysząc wiernym od początku do końca ich życia przez posługę liturgiczną, wyświęceni szafarze podtrzymują w nich życie Boże, między innymi dzięki łasce płynącej z sakramentów. Udzielając chrztu świętego, prowadzą człowieka do uwolnienia go od grzechu pierworodnego, obdarowania go życiem nadprzyrodzonym oraz uczynienia go synem Boga i Kościoła, przez co ochrzczony zaczyna swe zmagania z mocami ciemności. Zgodnie bowiem z najdawniejszą tradycją Kościoła drogę chrześcijańskiego wtajemniczenia ustanowiono tak, aby wyraźnie ukazać i rzeczywiście rozpocząć duchową walkę z władaniem diabła (zob. Ef 6, 12), o czym świadczy obecność egzorcyzmów

${ }^{27}$ Zob. SC 7; DP 2.

${ }_{28}$ Zob. DP 5; LG 10. 
w liturgii chrzcielnej oraz wyrzeczenie się Szatana, jego mocy i władzy ${ }^{29}$. Dzięki bierzmowaniu przez biskupa wierny otrzymuje łaskę i dary Ducha Świętego do skutecznej walki duchowej. Z kolei „pierwszym i podstawowym sposobem wyzwalania się spod panowania szatana jest sakrament pokuty i pojednania, gdzie Chrystus Zmartwychwstały daje nam udział w swoim zwycięstwie nad mocami ciemności i leczy w nas to, co grzech osłabił i poranił. Natomiast częste przyjmowanie Ciała Pańskiego broni nas najskuteczniej przed mocą Złego, który nie może się ostać w sercu, do którego wchodzi Ten, który wypędza demony"30. Częsta zatem celebracja sakramentu pokuty dzięki prezbiterom i biskupom daje członkom Kościoła moc dla osiągnięcia wolności dzieci Bożych (por. Rz 8, 21) i wyrwania się ze zniewolenia grzechem oraz zniszczenia przez to łącznika między człowiekiem a złym duchem. Natomiast sprawowanie Eucharystii uobecnia wydarzenie Krzyża, na którym Jezus złożył sam siebie w ofierze, by ani grzech (zob. Hbr 5, 1), ani Szatan nie miał władzy nad człowiekiem. Dotyczy to także samych prezbiterów, biskupów i walki przeciw duchowi kłamstwa. Jezus modlił się bowiem do Ojca: „Nie proszę, abyś ich zabrał ze świata, ale byś ich ustrzegł od złego. (...) A za nich Ja poświęcam w ofierze siebie samego, aby i oni byli uświęceni w prawdzie" (J 17, 15. 19). Oprócz sprawowania Najświętszej Ofiary, do której ważności konieczne są święcenia, kapłani urzędowi mogą też udzielać sakramentu namaszczenia chorych, w którym Duch Święty wspiera ciężko chorego bądź umierającego swą łaską przeciw szatańskiej pokusie rozpaczy i buntu oraz pomaga postrzegać cierpienie jako włączenie się w dzieło zbawienia Kościoła i świata. Biskupi jako następcy apostołów przekazują świętą władzę swoim następcom i pomocnikom poprzez święcenia, by kontynuować w zastępstwie Chrystusa Jego zbawcze posłannictwo jako Króla, Proroka i Kapłana w Kościele, którego „bramy piekielne nie przemogą” (Mt 16, 18). Osoby wyświęcone błogosławią również małżeństwa, odprowadzają zmarłych na miejsce ich wiecznego spoczynku, błagając dla nich o miłosierdzie Boże, wspierają modlitwą oraz udzielają błogosławieństw i innych sakramentaliów.

${ }^{29}$ Zob. Egzorcyzmy i inne modlitwy błagalne: rytuał rzymski odnowiony zgodnie z postanowieniem świętego Soboru Watykańskiego II, wydany z upoważnienia papieża Jana Pawła II, Katowice 2002, Wprowadzenie teologiczne i pastoralne, $\mathrm{nr} 8$.

${ }^{30}$ Konferencja Episkopatu Polski, Wskazania dla kapłanów pełniących posługe egzorcysty [dalej: KEP, Wskazania], $\mathrm{nr}$ 4, https://episkopat.pl/wskazania-dla-kaplanow-pelniacych-poslugeegzorcysty (30.12.2019). 
Szczególnym rodzajem celebracji liturgicznej, do której uprawnieni są tylko wyświęceni kapłani (prezbiterzy i biskupi) ${ }^{31}$, są egzorcyzmy, stanowiące inny niż sakramenty sposób wyzwolenia się spod panowania Szatana. Chodzi zwłaszcza o egzorcyzm większy, który jest obrzędem liturgicznym sprawowanym w celu „wypędzenia złych duchów lub uwolnienia od ich demonicznego wpływu mocą duchowej władzy, jaką Jezus powierzył Kościołowi”, a który może sprawować wyłącznie biskup lub wyznaczony i uprawniony przez niego prezbiter $^{32}$. Dzięki kapłańskiej posłudze możliwa jest ta celebracja liturgiczna jako dzieło Chrystusa oraz „anamnetyczna kontynuacja tego, co czynił Syn Boży i objawienie Jego czynu zbawczego, stanowiącego fundament liturgii, w której Chrystus zbawia, egzorcyzmuje, uwalnia i uzdrawia człowieka. W ten sposób liturgia przypomina nieustannie, że za pośrednictwem Chrystusa w egzorcyzmie dokonuje się wciąż święta wymiana i dialog pomiędzy Bogiem a człowiekiem. Chrystus Kapłan spełnia w niej dzieło Boga, prowadząc człowieka do spotkania z Ojcem, który udziela swoim udręczonym synom bogactwa wolności w Duchu Świętym. Egzorcyzm jest dla współczesnego świata także rodzajem autoapologii Chrystusa, który wciąż jako boski Legat sam zwiastuje, przypomina i uzasadnia światu prawdę o swoim kapłaństwie i Misterium Paschalnym, celebrowanym do końca czasów”33. Egzorcyzm, jak zatem każda celebracja liturgiczna, jest dziełem Chrystusa Kapłana i Jego Ciała - Kościoła, który uroczyście błaga Boga w zjednoczeniu z Duchem Świętym, aby przyszedł On z pomocą ludzkiej słabości w walce ze złymi duchami ${ }^{34}$. Jednakże udział członków Kościoła w tej celebracji diametralnie się różni, ponieważ Kościół od początków swego istnienia prowadzi czynną walkę ze złym duchem przez posługę egzorcystów. Wierni również włączeni są w te zmagania, ale nie w ten sam sposób, co wyświęcony biskup lub prezbiter egzorcysta, któremu przysługuje wyłączne prawo do właściwego sprawowania liturgii egzorcyzmu, wypowiadania formuł błagalnych i rozkazujących. Wierni asystujący takiemu prezbiterowi mogą go jedynie wspierać poprzez odmawiane w milczeniu modlitwy błagalne, zarówno za osobę opętaną, jak i za samego

${ }^{31}$ Celebracje egzorcyzmu mogą być wykonywane jedynie przez kapłanów urzędowych, do których nie należą diakoni, ponieważ nakłada się na nich ręce „nie dla kapłaństwa, lecz dla posługi” (LG 29).

${ }^{32}$ Zob. KEP, Wskazania, nr 4; Egzorcyzmy i inne modlitwy błagalne, dz. cyt., Wprowadzenie teologiczne i pastoralne, nr 11.

33 P. Towarek, Egzorcyzm, dz. cyt., s. 220-221.

${ }^{34}$ Zob. Egzorcyzmy i inne modlitwy błagalne, dz. cyt., Wprowadzenie teologiczne i pastoralne, $\mathrm{nr}$ 12. O egzorcyzmie jako formie epiklezy zob. P. Towarek, Egzorcyzm, dz. cyt., s. 222. 
egzorcystę. Ze względu na odmienną rolę, jaka przypadła im w udziale, nie mogą oni czynić nic więcej bez wyraźnego pozwolenia ze strony egzorcysty ${ }^{35}$.

Ukazuje to prawdę o tym, jak wielką moc i łaskę zawarł Chrystus w sakramencie święceń, zwłaszcza jeśli chodzi o zmaganie się Kościoła z siłami zła. Widać ją nie tylko w kapłańskim głoszeniu Słowa, którego moc wyrzuca demony, czy w sprawowaniu liturgii, przez którą Chrystus Kapłan uwalnia swój lud od panowania diabła, lecz także w kapłańskiej posłudze miłości i pomocy potrzebującym.

\section{Funkcja pasterska - „Wypędzajcie złe duchy” (Mt 10, 8)}

Posługa wyświęconych szafarzy jest posługą samego Kościoła i może być wypełniana jedynie we wspólnocie hierarchicznej całego Ciała Chrystusa ${ }^{36}$. Dlatego kapłaństwo zostało ustanowione dla wspólnoty Kościoła, a przez niego dla całej ludzkości, aby dzięki mocy i władzy otrzymanej od Chrystusa służyć sprawie zbawienia. Posługiwanie szafarzy polega między innymi na gromadzeniu ludu Bożego w duchu jedności i prowadzeniu go przez Chrystusa w Duchu Świętym do Ojca. Zjednoczeni w jedno ciało wierni pod przewodnictwem kapłańskim są zdolni do składania Bogu samych siebie w ofierze i oddawania Mu czci „w Duchu i prawdzie” (J 4, 24) ${ }^{37}$. Na mocy urzędu otrzymanego od Chrystusa i daru Ducha wyświęceni reprezentują i organizują jedność wspólnoty bogatej w różne charyzmaty, kierują nią, wspierając różnorakie zadania i posługi. W ten sposób wyświęcony szafarz pełni misję Chrystusa jako Głowy Kościoła, a istota Chrystusa jako Głowy Kościoła polega na byciu źródłem, początkiem i jednością własnego Kościoła ${ }^{38}$. Jest to niezwykle ważne w codziennej walce $\mathrm{z}$ „tym, który rozprasza” (Łk 11, 23), dlatego Jan Paweł II napisał w Reconciliatio et poenitentia: „Sakrament święceń ma dawać Kościołowi Pasterzy, którzy będąc nauczycielami i przewodnikami, powołani są ponadto do tego, by być świadkami i sprawcami jedności, budowniczymi rodziny Bożej, obrońcami i stróżami komunii tej rodziny przeciwko zaczynom podziału i rozproszenia"39. Dlatego osoby wyświęcone winny wsłuchiwać się

${ }_{35}$ Zob. KEP, Wskazania, nr 39, 42.

${ }^{36}$ Zob. DP 15.

37 Zob. LG 28.

${ }^{38}$ Por. G. L. Müller, Dogmatyka katolicka, dz. cyt., s. 766.

39 Jan Paweł II, Adhortacja apostolska Reconciliatio et poenitentia, Libreria Editrice Vaticana 1984, nr 27. 
w głos wiernych, na wzór Chrystusa z dobrocią i po bratersku rozpatrując ich pragnienia, uznając kompetencje i doświadczenie, „badać duchy”, czy pochodzą od Boga, w duchu wiary odkrywać wśród ludu Bożego dary Ducha, zwłaszcza te, które pociągają wielu do doskonalszego życia duchowego, oraz dbać o to, by każdy wierny został doprowadzony w Duchu Świętym do rozwoju swego powołania zgodnie w Ewangelią, do czynnej miłości i wolności w Chrystusie, a zatem do dojrzałości chrześcijańskiej. Mają pomagać im dostrzec wolę Bożą i dać bodziec do służby bliźnim na miarę swoich możliwości i łaski otrzymanej od Boga. Przede wszystkim wezwani są, by użyć swych sił do zapewnienia wzrostu duchowego Ciała Chrystusa, żeby jako wspólnota stało się narzędziem sprawczym, przez które niewierzącym ukazana zostaje droga do Chrystusa, a „wierni zostają pobudzeni, zasileni i wzmocnieni do duchowej walki"40. To zmaganie się osób wyświęconych z siłami ciemności odbywa się codziennie i zwyczajnie poprzez ich posługę słowa, sprawowanie kultu Bożego, udzielanie sakramentów i błogosławieństw. Jeśli chodzi o te ostatnie, to formuły błogosławieństw wyrażają nie tylko uwielbienie Boga za Jego dary i błaganie o Jego dobrodziejstwa, lecz także „prośbę o udaremnienie w świecie władzy złego ducha"41. Pomagają im w ten lub inny sposób walczyć z Szatanem, jednak należy podkreślić, że zasadniczą formą walki z nim jest zmaganie się człowieka z grzechem we własnym życiu, a w tej walce wiodącą rolę, jak już wspomniano, pełnią sakramenty Eucharystii oraz pokuty i pojednania.

Szczególnie powierzone są ich opiece osoby ubogie, słabsze, prześladowane, chore, doświadczone przez trudy życia, potrzebujące nie tyle materialnego, ile duchowego wsparcia. Do takich osób zaliczają się również ludzie szczególnie kuszeni i dręczeni przez demony, którym wyświęcony szafarz nie powinien odmawiać pomocy duchowej, wysłuchania i modlitwy o Boży pokój dla nich. Ludzie duchowo cierpiący nigdy nie powinni być traktowani powierzchownie, lecz z miłością, jaką Jezus okazywał wszystkim dręczonym przez złego ducha $^{42}$. Niekiedy zdarzają się przypadki nadzwyczajnej obecności Szatana w człowieku, takie jak opętania demoniczne. Wówczas konieczna jest pomoc

${ }^{40}$ DP 6; zob. DP 9.

${ }^{41}$ Komisja ds. Kultu Bożego i Dyscypliny Sakramentów, Rytuał. Obrzędy błogosławieństw, Wprowadzenie teologiczne i pastoralne, nr 11, https://opoka.org.pl/biblioteka/T/TA/TAL/kkbids/ rytual_obrzedy_blogoslawienstw.html (30.12.2019).

${ }_{42}$ Zob. Egzorcyzmy i inne modlitwy błagalne, dz. cyt., Wprowadzenie teologiczne i pastoralne, nr 15; KEP, Wskazania, nr 28. Gabriele Amorth podkreśla, że obojętność szafarzy zmusza ludzi do uciekania się do czarowników, wróżbitów i szarlatanów, zob. G. Amorth, Nowe wyznania egzorcysty, Częstochowa 1998, s. 116. 
biskupa lub prezbitera specjalnie wyznaczonego i przygotowanego do posługi egzorcyzmowania.

Egzorcyzmy są sakramentaliami, czyli świętymi znakami, które na podobieństwo sakramentów sprowadzają duchowe dobra dzięki wstawiennictwu Kościoła. Mówimy o nich, gdy Kościół publicznie oraz na mocy obowiązku i duchowej władzy otrzymanych od Chrystusa błaga w Jego imię, by osoba lub rzecz zostały uchronione od ataków Szatana i wolne od jego panowania. $\mathrm{W}$ formie prostej spotyka się je w modlitwie $\mathrm{z}$ egzorcyzmem odmawianej podczas chrztu dzieci przez szafarza chrztu, którym może być biskup, prezbiter bądź diakon. Z kolei egzorcyzmy mniejsze podczas skrutyniów to modlitwy odmawiane przez wyświęconego szafarza lub przygotowanego i upoważnionego przez biskupa katechetę, w których Kościół prosi Boga o uwolnienie dorosłych przygotowujących się do przyjęcia chrztu o uwolnienie od wpływu diabła i skutków grzechu oraz umocnienie w duchowej walce. Istnieją też egzorcyzmy nad przedmiotami i miejscami, które może odprawić każdy prezbiter za zgodą biskupa diecezjalnego. Natomiast modlitwy o ochronę przed wpływem demonicznym to modlitwy błagalne i wstawiennicze, które może odmówić każdy członek Kościoła nad osobami nękanymi przez złego ducha, z wyłączeniem przypadku opętania. Nie zawierają one formuły imperatywnej, bowiem jej użycie bez szczególnego wsparcia Kościoła może być niebezpieczne. Dlatego istnieje egzorcyzm większy, czyli uroczysty, będący ściśle określonym i unormowanym przez Kościół obrzędem liturgicznym, którego szafarzem może być wyłącznie biskup bądź wyznaczony i upoważniony przez niego prezbiter ${ }^{43}$. Ten egzorcyzm ma na uwadze sytuację opętania demonicznego, czyli sytuację, którą w wielkim skrócie można opisać jako zawładnięcie przez złego ducha ciałem człowieka i wpłynięcie w dużej mierze na jego zachowanie zewnętrzne, ale bez dotknięcia jego wolnej woli ${ }^{44}$. W nim Kościół w osobie prezbitera bądź biskupa zjednoczony z Duchem Świętym i ufny w moc Jego tchnienia błaga o Jego pomoc w walce ze złym duchem, by nie szkodził człowiekowi. W egzorcyzmie Kościół nie działa we własnym imieniu, lecz tylko

${ }^{43}$ Zgodnie z wymogiem prawa kanonicznego (zob. Kodeks prawa kanonicznego, przekład polski zatwierdzony przez Konferencję Episkopatu [dalej: KPK], tłum. E. Szafranowski, Poznań 2008, kan. 1172), o czym będzie mowa niżej.

${ }_{44}$ Zob. KEP, Wskazania, nr 4; KKK 1673; KPK, kan. 1172; Obrzędy chrztu dzieci dostosowane do zwyczajów diecezji polskich, Katowice 2005, nr 49; Obrzędy chrześcijańskiego wtajemniczenia dorostych dostosowane do zwyczajów diecezji polskich, Katowice 1988, nr 109-118. 
w imieniu Jezusa Chrystusa, któremu są posłuszne wszystkie stworzenia, także demony ${ }^{45}$.

Tę duchową władzę wypędzania złych duchów i uwalniania od ich wpływu Chrystus powierzył Kościołowi, który posłuszny Jego nakazom i słowom Modlitwy Pańskiej oraz powodowany miłosierdziem i troską o duchowe dobro człowieka sprawuje egzorcyzmy i ustanawia egzorcystów, by naśladując miłość Chrystusa, pomagali opętanym przez Złego i stanowili przeszkodę w szkodzeniu ludziom. Posługa egzorcysty jest przede wszystkim posługą miłosierdzia, świadectwem miłości i wypływającej z niej troski Boga o człowieka ${ }^{46}$.

Powołanie do niej biskupów i prezbiterów ${ }^{47}$ wynika $\mathrm{z}$ bezpośredniego imperatywu wyrażonego przez Jezusa Chrystusa - On powołując apostołów, udzielił im władzy głoszenia nauki, uzdrawiania chorych i panowania nad demonami: „wypędzajcie złe duchy” (Mt 10, 8; por. Mt 10, 1; Mk 3, 13-15; 6, 7. 13; $Ł k$ 9, $1 ; 6,12.18$ ). Walka Jezusa z Szatanem podczas Jego publicznej działalności widoczna jest już u jej początków (zob. Mk 1, 13) i na stałe wpisuje się w Jego dzieło, ponieważ zmierza ono do zniszczenia władzy diabła (zob. 1 J 3, 8) i wyzwolenia ludzi. Nader częste opisy egzorcyzmów Jezusa na kartach Ewangelii to zapowiedź tego, że „władca tego świata zostanie precz wyrzucony” (J 12, 31), a królestwo Jezusa będzie się rozwijać i nie będzie w nim miejsca dla złego ducha, gdyż Syn Boży nie ma z nim nic wspólnego (zob. J 14, 30), tak jak i ci, którzy do Niego należą (zob. 1 J 5, 18). W tym celu Chrystus posyła apostołów, w tym Pawła, by na Jego wzór jako tego, który uzdrawiał wszystkich będących „pod władzą diabła” (Dz 10, 38), otwierali ludziom oczy i odwracali ich „od ciemności do światła, od władzy szatana do Boga” (Dz 26, 18). Diabeł, zwyciężony przez Chrystusa, walczy przeciw Jego naśladowcom, dlatego Jezus udzielił szczególnej mocy apostołom, a potem innym uczniom, by mocą Jego imienia wyrzucali złe duchy ${ }^{48}$. Przekazanie im tej władzy i autorytetu pokazuje,

${ }^{45}$ Zob. Egzorcyzmy i inne modlitwy błagalne, dz. cyt., Wprowadzenie teologiczne i pastoralne, nr 12. Piotr Towarek podkreśla, że egzorcyzm jest świadectwem misji zbawczej oraz anamnezą Paschy Chrystusa, który mocą Krzyża przeprowadza ze śmierci do życia człowieka udręczonego przez diabła. Celebracja ma wymiar chrystocentryczny, bo jest dziełem samego Chrystusa Kapłana i kontynuacją tego, co czynił. On sam w liturgii egzorcyzmu rozkazuje złym duchom i uwalnia człowieka. Ma też wymiar pneumahagijny, bo jest nie tyle rozkazem skierowanym do Szatana, co raczej epiklezą, w której Duch Święty objawia swą moc w człowieku udręczonym, biorąc go w swe posiadanie. Por. P. Towarek, Egzorcyzm, dz. cyt., s. 254.

${ }^{46}$ Zob. KEP, Wskazania, nr 6, 21.

47 Jeśli chodzi o diakonów, zob. przypis 31.

${ }^{48}$ Por. G. Amorth, Nowe wyznania egzorcysty, dz. cyt., s. 28-31, 34-36; KEP, Wskazania, nr 1. 
że Jezus przykłada do niej szczególną wagę i mimo połączenia z uzdrawianiem chorych, kładzie na nią nacisk i odróżnia od tej drugiej władzy (zob. Mk 1,34).

Jezus wyrzucał demony słowem (zob. Mt 8, 16) i palcem Bożym (zob. Łk 11, 20), czyli mocą Ducha Świętego. Nie był to akt magiczny łączący się z zaklinaniem demona w czyjeś imię, ale niepowtarzalny znak mocy i objawienie prawdy o tym, że to Jezus jest „Mocarzem”, Synem Bożym i oczekiwanym Mesjaszem (zob. Łk 11, 21-22; Mk 3, 27), który nadał egzorcyzmom nowy sens. Wiara w moc imienia Jezusa oraz post i modlitwa (zob. Mk 9, 14-29) są podstawą egzorcyzmów Kościoła pierwszych wieków (zob. Dz 8, 5-7; 16, 16-18; 19, 11-16) oraz podkreśleniem prawdy, że z Jezusa - największego Egzorcysty czerpie siłę każda walka przeciw złemu duchowi, a egzorcyzm jest anamnezą osoby i czynu Syna Bożego, który obecny w Kościele aż do końca czasów wciąż egzorcyzmuje i zwycięża złego ducha ${ }^{49}$.

Po zmartwychwstaniu Chrystus przekazał tę władzę całemu Kościołowi (zob. Mk 16, 15-18) i na podstawie tego mandatu w Kościele pierwotnym do połowy III wieku każdy chrześcijanin obdarzony charyzmatem (gratia sanitatum) mógł sprawować egzorcyzm, zwłaszcza że nie było specjalnego urzędu egzorcysty. Dość wcześnie doszło do zarezerwowania tej władzy dla określonej kategorii osób - na Wschodzie uznawano szczególny charyzmat, na Zachodzie - nominację kościelną. W obu przypadkach egzorcyzm rozwijał się w czasie w dwóch odrębnych formach: jako modlitwa ukierunkowana na wyzwolenie opętanego i jako modlitwa stanowiąca część sakramentu chrztu. Z relacji papieża Korneliusza można wywnioskować, że w czasach wczesnochrześcijańskich egzorcyści stanowili w Kościele liczną grupę. Ryty przedchrzcielne dopełniające obrzędy egzorcyzmów sprawowali prezbiterzy oraz diakoni i diakonisy (jeśli chodzi o namaszczenie), natomiast ostateczny uroczysty egzorcyzm celebrowany był przez biskupa. Z czasem posługa egzorcystyczna stała się urzędem i stopniem do przyjęcia święceń prezbiteratu, a ostatecznie została związana ze szczególną misją, której udziela biskup ${ }^{50}$.

49 Por. P. Towarek, Egzorcyzm, dz. cyt., s. 39, 43.

${ }^{50}$ Por. G. Amorth, Nowe wyznania egzorcysty, dz. cyt., s. 46; P. Towarek, Egzorcyzm, dz. cyt., s. 68-69. Bardziej szczegółowy opis historii posługi i święceń egzorcysty w Kościele zob. R. Laurentin, Szatan. Mit czy rzeczywistość, Warszawa 1998, s. 94-101; P. Towarek, Geneza i kształtowanie się posługi egzorcysty w Kościele, „Studia Elbląskie” 8 (2007), s. 111-122. Paweł VI wydał motu proprio Ministeria quaedam z 15.07.1972 o zniesieniu niższych święceń egzorcystatu i nazwaniu go posługą, którą poszczególne konferencje biskupie za zgodą Stolicy Apostolskiej mogą ustanowić, jeśli uważałyby to ze szczególnych względów za konieczne lub bardzo pożyteczne. Zob. Paulus VI, Littera apostolica motu proprio Ministeria quaedam, „Acta Apostolicae Sedis” [dalej: AAS] 64 (1972), 
On właśnie, jako następca apostołów, jest znakiem realizacji otrzymanej od Chrystusa misji Kościoła dotyczącej wypędzania demonów, i to on udziela pozwolenia odpowiednio przygotowanemu do tego zadania prezbiterowi.

Na posłuszeństwie i wierności biskupowi diecezjalnemu, który jest zawsze znakiem jedności Kościoła, opiera się władza egzorcysty nad mocami ciemności ${ }^{51}$ - w dodatkach do rytuału egzorcyzmu wskazane są źródła jego misji: „na mocy świętej posługi powierzonej mi przez władzę Kościoła z ufnością przystępuję do odparcia ataków diabelskiej przewrotności" ${ }^{52}$. Skuteczność egzorcyzmu zależy zatem od tej władzy i modlitwy całego Kościoła (ex opere operantis Eccleasie), który uobecnia się w osobie wyświęconego egzorcysty, dlatego może on bezpośrednio zwracać się do złego ducha ${ }^{53}$. Wielkie znaczenie ma zatem władza otrzymana na mocy sakramentu święceń, ponieważ pozwala wyświęconemu sprawować liturgię egzorcyzmu, a podczas niego uobecniać Chrystusa i Jego „władzę stąpania po wężach i skorpionach, i po całej potędze przeciwnika” (Łk 10, 19), którą przekazał apostołom. Biskupi jako następcy apostołów posiadają tę władzę ex officio, a ich współpracownicy prezbiterzy muszą ku temu otrzymać od nich specjalny mandat, pomimo tego, że władza dokonywania egzorcyzmów zawiera się we władzy święceń.

Prawo kanoniczne wymaga „specjalnego i wyraźnego zezwolenia” ${ }^{4}$, a zatem nie może to być zezwolenie milczące lub domniemane bądź ogólne dla wszystkich prezbiterów. Możliwe jest natomiast zezwolenie udzielone określonemu prezbiterowi dla ogółu różnych przypadków opętania. Udziela

s. 529-534. Dokument Kongregacji Nauki Wiary pod tytułem Wiara chrześcijańska i demonologia z 1975 roku stwierdza, iż to, że egzorcystat jest posługą okazjonalną i wykonywaną tylko na prośbę biskupa bez żadnego obrzędu do jej przekazania, nie oznacza, że kapłan nie ma już uprawnień do egzorcyzmowania, ani że nie musi go już wykonywać. Jest to po prostu oznaka tego, że Kościół nie przywiązuje już tej samej wagi do egzorcyzmów, co w poprzednich wiekach. Zob. http://www. vatican.va/roman_curia/congregations/cfaith/documents/rc_con_cfaith_doc_19750626_fedecristiana-demonologia_en.html\#top (30.12.2019).

${ }^{51}$ Władzę biskupa potwierdza na przykład tekst śpiewany podczas święceń biskupich przez głównego szafarza: „niech posiada na mocy najwyższego kapłaństwa władzę odpuszczania grzechów zgodnie z Twoim poleceniem, niech rozdziela posługi według Twego rozkazu i rozwiązuje z wszelkich więzów na mocy władzy, jaką dałeś Apostołom” (Obrzęd święceń biskupa, prezbiterów i diakonów, Katowice 1999, nr 47, 83).

${ }_{52}$ Rituale Romanum. De exorcismis et supplicationibus quibusdam, Città del Vaticano 1999, Appendices I, 7.

53 Por. P. Towarek, Egzorcyzm, dz. cyt., s. 232-233.

54 KPK, kan. 1172. 
go ordynariusz miejsca ${ }^{55}$. Nie każdy jednak prezbiter i nie w każdych okolicznościach może uzyskać tę licencję i dokonywać egzorcyzmów. Musi to być tylko prezbiter odznaczający się „pobożnością, wiedzą, roztropnością i nieskazitelnością życia” oraz odpowiednio do tego przygotowany. Wtedy dopiero jest uprawniony do wypowiadania formuł egzorcyzmu większego, a każdy inny przypadek, taki jak brak wyraźnego zezwolenia, brak święceń czy brak predyspozycji i przygotowania jest nadużyciem, aktem bezprawnym, a przez to grzesznym ${ }^{56}$.

W modlitwie egzorcyzmu egzorcysta jest sługą i narzędziem Kościoła, jednak udzielenie mu przez Kościół wspomnianego pełnomocnictwa, pomimo swego wielkiego znaczenia, nie oznacza równoczesnego nadania ex opere operato najwyższego charyzmatu ani umiejętności potrzebnych do sprawowania tej posługi. Niezbędne jest po pierwsze przygotowanie teoretyczne, obejmujące elementy teologii dogmatycznej, dobrą i integralną znajomość księgi Egzorcyzmy i inne modlitwy błagalne oraz podstawową wiedzę z wybranych zagadnień psychologii. Po drugie, konieczne jest przygotowanie praktyczne polegające na korzystaniu z pomocy bardziej doświadczonego i odpowiedzialnego egzorcysty, który wprowadzi nowego szafarza prezbitera w posługę egzorcyzmowania, pokaże schemat postępowania podczas obrzędu egzorcyzmu, modlitw i działań dodatkowych oraz uwrażliwi na „przyjęcie postawy wiary, ducha

55 Pod tym pojęciem należy rozumieć biskupa diecezjalnego oraz wszystkich z nim zrównanych w prawie, czyli prałata terytorialnego, opata terytorialnego, wikariusza apostolskiego, prefekta apostolskiego, administratora apostolskiego oraz wikariusza generalnego i wikariusza biskupiego. Ordynariusz miejsca może udzielić zezwolenia swojemu prezbiterowi (inkardynowanemu), a także obcemu (nieinkardynowanemu), na przykład prezbiterowi zakonnemu, jednak dotyczy ono i może być wykonywane tylko na terytorium podległym ordynariuszowi miejsca. Ów mandat może być udzielony na stale, czasowo lub do konkretnego przypadku. Zob. Relacja egzorcyści - biskup diecezjalny i konferencja biskupów, w: W blasku Chrystusa i cieniu szatana, red. B. Barkowski, A. Posacki, Warszawa 2004, s. 205-206.

56 Zob. KPK, kan. 1172; R. Dappa, Egzorcysta i jego posługa w prawie kodeksowym i pozakodeksowym, „Kościół i Prawo” 7 (20) (2018) nr 1, s. 130, 135; KEP, Wskazania, nr 8-9, 13; Egzorcyzmy i inne modlitwy błagalne, dz. cyt., Wprowadzenie teologiczne i pastoralne, nr 13. Rytuał egzorcyzmów z 1614 roku tak opisywał cechy egzorcysty: „Kapłan, któremu została powierzona - na mocy specjalnego i wyraźnie określonego upoważnienia ordynariusza - funkcja egzorcyzmowania osób dręczonych przez demona, winien odznaczać się pobożnością, roztropnością i uczciwością, pokładać ufność nie w sile własnej, lecz w sile Boga; wszelkie pożądanie dóbr doczesnych musi mu być obce, a tak święte dzieło ma spełniać, kierując się miłosierdziem, z wytrwałością i pokorą. Poza tym wypada, by był człowiekiem w wieku dojrzałym i szanowanym ze względu nie tylko na swój urząd, lecz także godne obyczaje" (cyt. za R. Laurentin, Szatan..., dz. cyt., s. 236). 
służby i posłuszeństwa biskupowi diecezjalnemu"s7. W swojej posłudze egzorcysta powinien mieć i pogłębiać świadomość, że korzenie jego działania tkwią w wierze Kościoła koniecznej do sprawowania rytu egzorcyzmu oraz wzorować się na Chrystusie uwalniającym człowieka od demonów i otwierającym przed nim na nowo drzwi do zbawienia i świętości. W tym potrzebne jest mu wsparcie i nabożeństwo do Ducha Świętego oraz osobiste zaangażowanie w godne i owocne sprawowanie rytuału, szczególnie przez modlitwę i post. Stanięcie w obliczu działania kochającego Boga w egzorcyzmie „powinno owocować w jego życiu duchowym jeszcze większym pragnieniem świętości budowanej na pokorze. Jako pierwszy wezwany jest do przyjęcia postawy człowieka, który całkowicie jest oddany panowaniu Boga"s8.

Rola egzorcysty nie kończy się na celebracji rytu. Egzorcysta winien kontynuować swą posługę miłości wobec człowieka atakowanego przez siły zła także po jego uwolnieniu ze stanu opętania. Trzeba bowiem wspomóc człowieka w odnalezieniu drogi do Boga i Kościoła, w ukazaniu i przywróceniu mu właściwego poczucia grzechu, wyjaśnieniu mu tego, na czym polegały błędy dające przystęp złym duchom, w umożliwieniu mu uczestnictwa w rekolekcjach ewangelizacyjnych, $w$ dokonaniu rachunku sumienia i usunięciu przeszkód dla łaski Bożej oraz w przylgnięciu do Jezusa jako jedynego Pana i Zbawcy ${ }^{59}$. Wyświęcony szafarz pełni zatem fundamentalną rolę, jeśli chodzi o rytuał egzorcyzmu i wyzwalanie ludzi ze strefy wpływów złego ducha po jego celebracji. Przypadła mu bowiem rola, której nie może pełnić żaden wierny świecki. Chociaż zgodnie z obietnicą Chrystusa (zob. Mk 16, 17) każdy chrześcijanin może prywatnie modlić się o ochronę przed złym duchem dla siebie lub innych, opierając się na wierze i ufności w moc Bożego miłosierdzia i jest nawet do tego wezwany we wspólnocie Kościoła, to jednak sam z siebie nigdy nie stanie się egzorcystą. Nie ma bowiem ani władzy, ani powołania do celebracji tego obrzędu, a tym bardziej do używania imperatywnych formuł egzorcystycznych zarezerwowanych dla egzorcysty, którym może być tylko wyświęcony prezbiter lub biskup ${ }^{60}$. Sytuacja, w której świecki bądź prezbiter bez zezwolenia

57 KEP, Wskazania, nr 10; zob. R. Laurentin, Szatan ..., dz. cyt., s. 211. Etapy i kształt formacji egzorcysty: KEP, Wskazania, $\mathrm{nr}$ 14, 16, 18.

${ }_{58}$ KEP, Wskazania, nr 35; także nr 15, 33.

59 Zob. KEP, Wskazania, nr 38.

${ }^{60}$ Zob. KEP, Wskazania, nr 7, 12; KKK 1669; Egzorcyzmy i inne modlitwy błagalne, dz. cyt., Wprowadzenie teologiczne i pastoralne, nr 35; Congregatio pro Doctrina Fidei, Epistula Ordinariis locorum missa: in mentem normae vigentes de exorcismis revocantur Inde ab aliquot annis, AAS 77 (1985), s. 1169-1170; Kongregacja Nauki Wiary, Instrukcja na temat modlitw w celu osiągnięcia 
dopuszcza się nadużycia w postaci przypisania sobie prerogatyw egzorcysty, jest nie tylko grzeszna, ale i niebezpieczna. Relacja biblijna (zob. Dz 19, 13-16) oraz stanowiska egzorcystów ${ }^{61}$ wskazują, że zły duch nie ma litości dla ludzi, którzy chcą czynić to, do czego nie są powołani, ani na co nie mają zezwolenia, gdyż demona przed wyrządzeniem szkody nie powstrzymuje moc Kościoła, udzielona przez Chrystusa. Wspomniany zakaz egzorcyzmów dla świeckich podyktowany jest zatem względami bezpieczeństwa, nie tylko fizycznego, ale także, a nawet przede wszystkim duchowego, ponieważ grzeszna sytuacja, jaką stanowi to nadużycie, daje przystęp diabłu, którego miało się zamiar wrzucić z drugiego człowieka.

Rzymski egzorcysta Gabriele Amorth podkreślał, że uwalnianie od wpływów złego ducha jest niezbywalną częścią powołania kapłańskiego. Według niego szczególną władzę mają wszyscy prezbiterzy, również ci, którzy nie są egzorcystami, ponieważ wynika to $\mathrm{z}$ ich kapłaństwa urzędowego, będącego służbą wiernym w ich potrzebach duchowych, wśród których znajduje się też potrzeba uwolnienia od wpływu Złego ${ }^{62}$. Dlatego uwidocznił różnicę między modlitwą o uwolnienie a egzorcyzmem wedle kryterium osobowego: świecki, modląc się o wyzwolenie od Szatana, wyraża modlitwę prywatną, dzięki której bierze udział w powszechnym kapłaństwie wiernych i we władzy udzielonej przez Jezusa wierzącym w Niego; prezbiter modlący się w tym samym celu także odprawia modlitwę prywatną, lecz ma ona o tyle większą skuteczność, o ile włącza się w nią kapłaństwo urzędowe i potęga jego błogosławieństwa; z kolei egzorcysta celebrujący egzorcyzm ma większą skuteczność, ponieważ sprawuje sakramentalium, a więc odmawia modlitwę publiczną, przez którą odwołuje się do wstawiennictwa Kościoła. Nie bez znaczenia jest również wiara, ponieważ nawet modlitwa świeckiego czy prezbitera niebędącego egzorcystą odmawiana $\mathrm{z}$ wielką wiarą może być skuteczniejsza od modlitwy egzorcyzmu prezbitera wyznaczonego przez biskupa, który działa z mniejszą wiarą ${ }^{63}$.

Władza otrzymana w sakramencie święceń odgrywa jednak w działaniach antydemonicznych kluczową rolę. Amorth w swych publikacjach ubolewał

uzdrowienia pochodzącego od Boga Ardens felicitatis, nr 8, http://www.vatican.va/roman_curia/ congregations/cfaith/documents/rc_con_cfaith_doc_20001123_istruzione_pl.html (30.12.2019);

R. Dappa, Egzorcysta i jego posługa..., dz. cyt., s. 134 .

${ }^{61}$ Por. G. Amorth, Wyznania egzorcysty, Częstochowa 1997, s. 206.

62 Zob. G. Amorth, Wyznania egzorcysty, dz. cyt., s. 163.

${ }_{63}$ Por. G. Amorth, Nowe wyznania egzorcysty, dz. cyt., s. 98-99. Przykładem jest św. Katarzyna ze Sieny, do której egzorcyści przysyłali opętanych, których nie byli w stanie uwolnić. Dopiero jej modlitwa wyrastająca z wielkiej wiary wypraszała końcowe wyzwolenie. 
nad zaniedbywaniem wykonywania tych działań przez prezbiterów i biskupów ${ }^{64}$. We władzy egzorcysty, która została mu powierzona przez biskupa, widział dopełnienie swego kapłaństwa i twierdził, że powinna być obowiązkiem i częścią zwyczajnego duszpasterstwa. Nawoływał prezbiterów do uwierzenia w wartość swego kapłaństwa, we władze, których udzielił im Chrystus, oraz do naśladowania przykładu apostołów i świętych kapłanów. Przestrzegał przed tchórzostwem wobec diabła i lękiem przed jego odwetem, które uważał za bezpodstawne oraz nazywał „błędem”, „brakiem zaufania we wsparcie Chrystusa” i „zdradą kapłańskiego posłannictwa”. Kapłańskie posłannictwo powinno być całkowicie poświęcone prowadzeniu ludzi do Boga przez wyrwanie ich z mocy diabła dzięki głoszeniu słowa Bożego, sprawowaniu sakramentów i udzielaniu sakramentaliów, do których należy egzorcyzm. Zwrócił też uwagę na wielkie korzyści, jakie przyniosła mu posługa egzorcysty z perspektywy duchowej: korzyści dla wiary, ponieważ niemal namacalnie dotyka się świata niewidzialnego, oraz dla pokory i modlitwy, gdyż nieustannie doświadcza się bezsilności wobec przejawów zła i ma się świadomość, że to Bóg dokonuje wszystkiego, wspierając swego "sługę nieużytecznego" ${ }^{65}$. Nawołując prezbiterów i biskupów do niezaniedbywania obowiązku działania antydemonicznego i celebrowania egzorcyzmów, zacytował swego mistrza Candido Amantiniego, który stwierdził, że ów obowiązek nie jest związany z osobą prezbitera, ale z jego kapłaństwem i z nakazem Jezusa: „wyrzucajcie złe duchy”, a owa aktywność stanowi działanie Kościoła, który jest Kościołem walczącym ${ }^{66}$. Podkreślona została w ten sposób nieoceniona i podstawowa rola, jaką osoby wyświęcone pełnia w walce $\mathrm{z}$ królestwem ciemności.

Jak już wspomniano w początkowej części tego studium, ze względu na obszerność tematu zaprezentowane treści stanowią jedynie próbę ujęcia

${ }^{64}$ Jednemu z biskupów powiedział: „Jesteście następcami apostołów z nominacji. Ale to od was zależy, czy będziecie ich naśladowcami. Jeśli nie odprawiacie egzorcyzmów, nie działacie tak, jak oni działali”, zaś wobec prezbiterów wystosował zarzut, że wielu cierpień wiernych dałoby się uniknąć, gdyby „kapłani wierzyli w słowa Chrystusa i w moc, jak została im przekazana” (G. Amorth, Nowe wyznania egzorcysty, dz. cyt., s. 17-18). Brak wiary i zaniedbywanie przez kapłanów swej władzy egzorcystów nazywa „zdradą wobec nakazu Chrystusa” (G. Amorth, Wyznania egzorcysty, dz. cyt., s. 70). Ksiądz Józef Kozłowski pisał: „Przed (...) laty uderzyły mnie słowa: czy wykorzystujesz to wszystko, co otrzymałeś przez nałożenie rąk? I wtedy rozpoczęły się nabożeństwa o uzdrowienie i uwolnienie" (J. Kozłowski, $Z$ doświadczeń modlitwy o uwolnienie i uzdrowienie, w: W blasku Chrystusa..., dz. cyt., s. 67).

${ }_{65}$ Zob. G. Amorth, Wyznania egzorcysty, dz. cyt., s. 209-212.

66 Zob. G. Amorth, Nowe wyznania egzorcysty, dz. cyt., s. 150. 
sakramentu święceń z perspektywy antydemonicznej. To raczej zwrócenie na tę płaszczyznę uwagi i uwypuklenie jej pod wpływem apelu papieża Franciszka. Sprawą wielkiej wagi w walce duchowej jest bowiem pogłębiona świadomość istnienia tego aspektu sakramentu święceń u osób wyświęconych i u wiernych, którzy u nich szukają pomocy i wsparcia. Ukazanie „antydemoniczności” funkcji wynikających z tego sakramentu, czyli nauczycielskiej (posługa słowa), kapłańskiej (sprawowanie kultu) i królewskiej (władza polegająca na służbie innym i dbaniu o jedność) jest jednocześnie uwidocznieniem ich wymiaru soteriologicznego, czyli wyzwolenia ludzi przez Chrystusa spod władzy grzechu, śmierci i diabła poprzez posługę wyświęconych szafarzy świętych tajemnic. Nie można też zapominać o drugim aspekcie tego wymiaru, którym jest uświęcenie poprzez posługę kapłańską. W Bożym dziele zbawienia nie jest bowiem najważniejsze skupienie się na działaniu złych mocy i na zerwanej z Bogiem relacji. Fundament stanowi przecież uwypuklenie Jego zbawczej interwencji w jej ponownym nawiązaniu i uzdrowieniu, co samo w sobie niszczy moc diabła.

\section{ABstrakT}

Dzięki sakramentowi święceń biskup, prezbiter i diakon otrzymuje od Chrystusa władzę głoszenia słowa Bożego, sprawowania liturgii i prowadzenia posługi miłosierdzia, do której zalicza się troska o osoby dręczone przez diabła. Dzięki ich posłudze Chrystus nadal troszczy się o swój lud, ponieważ głoszą „naukę z mocą” (Mk 1, 27) zdolną wyrzucać złe duchy, zaś biskupi i prezbiterzy celebrują sakramenty ograniczające strefę wpływów królestwa ciemności w duszach ludzi oraz sprawują egzorcyzmy, czyli wyzwalają człowieka spod władzy i wpływów demona.

\section{SŁOWA KLUCZOWE}

sakrament święceń, Szatan, egzorcyzm

\section{Abstract}

\section{Antidemonic Character of the Sacrament of Holy Orders.}

Through the sacrament of Holy Orders, the bishop, priest and deacon receive authority from Christ to proclaim the word of God, to perform the liturgy and to conduct the service of mercy, which includes care for people tormented by the devil. Through their ministry, Christ still cares for his people because they proclaim "a teaching with authority" (Mark 1:27) capable of casting out evil spirits. Bishops and priests celebrate the sacraments limiting the sphere of influence of the kingdom of darkness 
in the souls of people and perform exorcisms, which liberate man from the power and influence of a demon.

\section{KEYWORDS}

The sacrament of Holy Orders, Satan, exorcism

\section{BiBLIOGRAFIA}

Amorth G., Nowe wyznania egzorcysty, Częstochowa 1998.

Amorth G., Wyznania egzorcysty, Częstochowa 1997.

Breviarium fidei. Wybór doktrynalnych wypowiedzi Kościoła, red. I. Bokwa, Poznań 2007.

Congregatio pro Doctrina Fidei, Epistula Ordinariis locorum missa: in mentem normae vigentes de exorcismis revocantur Inde ab aliquot annis, „Acta Apostolicae Sedis" 77 (1985), s. 1169-1170.

Dappa R., Egzorcysta i jego posługa w prawie kodeksowym i pozakodeksowym, „Kościół i Prawo" 7 (20) (2018) nr 1, s. 127-137.

Egzorcyzmy $i$ inne modlitwy błagalne: rytuat rzymski odnowiony zgodnie $z$ postanowieniem świętego Soboru Watykańskiego II, wydany z upoważnienia papieża Jana Pawła II, Katowice 2002.

Ficoń M., Antydemoniczny charakter sakramentu namaszczenia chorych, „Analecta Cracoviensia" 51 (2019), s. 35-64.

Franciszek, Adhortacja apostolska Gaudete et exsultate, http://www.vatican.va/content/francesco/pl/apost_exhortations/documents/papa-francesco_esortazione-ap_20180319_gaudete-et-exsultate.html (30.12.2019).

Guzowski K., Duch dialogujący, Lublin 2016.

Jan Paweł II, Adhortacja apostolska Reconciliatio et poenitentia, Libreria Editrice Vaticana 1984.

Jan Paweł II, Adhortacja posynodalna Pastores dabo vobis, http://w2.vatican.va/content/john-paul-ii/pl/apost_exhortations/documents/hf_jp-ii_exh_25031992_pastores-dabo-vobis.html (30.12.2019).

Jan Paweł II, Wierzę w Boga Ojca Stworzyciela, Città del Vaticano 1987.

Katechizm Kościoła Katolickiego, Poznań 1994.

Kodeks prawa kanonicznego, przekład polski zatwierdzony przez Konferencję Episkopatu, tłum. E. Szafranowski, Poznań 2008.

Komisja ds. Kultu Bożego i Dyscypliny Sakramentów, Rytuał. Obrzędy błogosławieństw, https://opoka.org.pl/biblioteka/T/TA/TAL/kkbids/rytual_obrzedy_blogoslawienstw.html (30.12.2019). 
Konferencja Episkopatu Polski, Wskazania dla kapłanów pełniacych postugę egzorcysty, https://episkopat.pl/wskazania-dla-kaplanow-pelniacych-posluge-egzorcysty (30.12.2019).

Kongregacja Nauki Wiary, Instrukcja na temat modlitw w celu osiągnięcia uzdrowienia pochodzącego od Boga Ardens felicitatis, http://www.vatican.va/roman_curia/ congregations/cfaith/documents/rc_con_cfaith_doc_20oo1123_istruzione_pl.html (30.12.2019).

Kongregacja Nauki Wiary, Wiara chrześcijańska i demonologia, http://www.vatican.va/ roman_curia/congregations/cfaith/documents/rc_con_cfaith_doc_19750626_fede-cristiana-demonologia_en.html\#top (30.12.2019).

Kozłowski J., $Z$ doświadczeń modlitwy o uwolnienie i uzdrowienie, w: $W$ blasku Chrystusa i cieniu szatana, red. B. Barkowski, A. Posacki, Warszawa 2004, s. 67-74.

Laurentin R., Szatan. Mit czy rzeczywistość, Warszawa 1998.

Müller G. L., Dogmatyka katolicka, przeł. W. Szymona, Kraków 2015.

Obrzęd święceń biskupa, prezbiterów i diakonów, Katowice 1999.

Obrzędy chrześcijańskiego wtajemniczenia dorostych dostosowane do zwyczajów diecezji polskich, Katowice 1988.

Obrzędy chrztu dzieci dostosowane do zwyczajów diecezji polskich, Katowice 2005.

Paulus VI, Littera apostolica motu proprio Ministeria quaedam, „Acta Apostolicae Sedis" 64 (1972), s. 529-534.

Pismo Święte Starego i Nowego Testamentu, Poznań 2003, wyd. 5 poprawione (Biblia Tysiąclecia).

Pius XI, Encyklika Ad catholici sacerdotii, https://opoka.org.pl/biblioteka/W/WP/ pius_xi/encykliki/ad_catholici_sacerdotii_20121935.html (30.12.2019).

Relacja egzorcyści - biskup diecezjalny i konferencja biskupów, w: W blasku Chrystusa i cieniu szatana, red. B. Barkowski, A. Posacki, Warszawa 2004, s. 205-207.

Rituale Romanum. De exorcismis et supplicationibus quibusdam, Città del Vaticano 1999.

Sobór Watykański II, Dekret o posłudze i życiu prezbiterów Presbyterorum ordinis, w: Sobór Watykański II, Konstytucje, dekrety, deklaracje, red. M. Przybył, Poznań 2002, s. 478-508.

Sobór Watykański II, Konstytucja dogmatyczna o Objawieniu Bożym Dei verbum, w: Sobór Watykański II, Konstytucje, dekrety, deklaracje, red. M. Przybył, Poznań 2002, s. 305-363.

Sobór Watykański II, Konstytucja dogmatyczna o Kościele Lumen gentium, w: Sobór Watykański II, Konstytucje, dekrety, deklaracje, red. M. Przybył, Poznań 2002, s. 105-170. Sobór Watykański II, Konstytucja o liturgii świętej Sacrosanctum Concilium, w: Sobór Watykański II, Konstytucje, dekrety, deklaracje, red. M. Przybył, Poznań 2002, s. $40-70$. 
Tomasz z Akwinu, Suma teologiczna, t. 31: Sakrament chorych (Supl. 29-33); Kapłaństwo (Supl. 34-4o), przełożył i w objaśnienia zaopatrzył R. Kostecki, London 1985. Towarek P., Egzorcyzm. Historia, liturgia, teologia, Olsztyn 2013.

Towarek P., Geneza i kształtowanie się posługi egzorcysty w Kościele, „Studia Elbląskie” 8 (2007), s. 111-122. 